\title{
Survivability of Black Small-Scale Sugar-cane Growers in the Ugu District Municipality of KwaZulu-Natal, South Africa
}

\author{
Mandla Mkhungo \\ Graduate School of Business and Leadership \\ University of KwaZulu-Natal, Durban, South Africa \\ Paul Green \\ Durban University of Technology, Durban, South Africa \\ Cecile N. Gerwel Proches \\ Graduate School of Business and Leadership \\ University of KwaZulu-Natal, Durban, South Africa
}

\section{Keywords}

sugar-cane industry, farming, small-scale farmers, challenges, qualitative research, South Africa

\begin{abstract}
This research sought to determine survivability of Black Small-Scale Sugar-cane Growers (BSSSGs), in the Ugu District Municipality of KwaZulu-Natal, South Africa, amid the severe decline in the sugar-cane industry. The qualitative research approach was employed. Fifteen in-depth, semi-structured interviews were conducted. Data were analysed using thematic analysis. The study revealed, among other things, that the majority of respondents were optimistic about the future of the industry, and as such, were planning to add to the existing hectares of sugar-cane planted. Notwithstanding evidence of the decline in profitability, which is advanced as one of the drivers of the industry decline, most BSSSGs stated profit as the motive for the planned increase in hectares. On the causes for the industry decline, only a handful of farmers linked this to international competitiveness, while others indicated transport costs as one of the drivers of the decline. Furthermore, the Reconstruction and Development Programme (RDP) Housing Scheme and the Land Restitution Programme were also mentioned by farmers as contributing significantly to loss of productive cane land to competing uses, for reasons discussed in detail in the study. Key lessons may be learned from this study to enhance survivability within the industry. The research findings are critical for addressing challenges that impede the survivability of BSSSGs in South Africa.
\end{abstract}

Corresponding author: Cecile N. Gerwel Proches

Email addresses for corresponding author: gerwel@ukzn.ac.za

First submission received: 15th May 2017

Revised submission received: 11th September 2017

Accepted: 28th September 2017

\section{Introduction}

The sugar-cane industry within the Ugu District Municipality in KwaZulu-Natal, South Africa, has experienced a sharp downturn of recent times (Phatisa, 2010a; Phatisa, 2010b). In terms of agriculture, sugar-cane is an important output for the Ugu District (Davis, Zunckel \& Kruger, 2012; Ugu District Municipality, 2012; Ugu District Municipality, n.d.). Ortmann (2005) observed declining employment in the agricultural sector, caused by substitution of labour by automation, labour contractors, and other labour-saving technologies. The sugar-cane industry of Ugu District Municipality was under siege by factors emanating mostly from the international arena, as well as, to some degree, the domestic. Black Small-Scale Sugar-cane Growers (BSSSGs), for a number of reasons, tend to be inherently more vulnerable than commercial farmers. The study therefore explored to what extent BSSSGs in the Ugu District Municipality are surviving in an industry which is under siege from international competition, and which has recorded an en masse exodus of large-scale commercial farmers (Phatisa, 2010a; Phatisa, 2010b).

Tables 1, 2 and 3, highlight total cane delivery, area under cane production and area harvested respectively within Ugu District Municipality. 
Table 1: Total tons of Cane Supply Deliveries in Ugu District Municipality during seasons 2006/7 and 2015/16

\begin{tabular}{|lllll|}
\hline Scale of Grower & $\begin{array}{l}\text { Season } \\
\mathbf{2 0 0 6 / 2 0 0 7}\end{array}$ & $\begin{array}{l}\text { Season } \\
\mathbf{2 0 1 5 / 1 6}\end{array}$ & $\begin{array}{l}\text { Output Decline in } \\
\text { tons }\end{array}$ & \% Decline \\
\hline Large-scale growers & $2,376,595$ & $1,680,107$ & 616,488 & $29 \%$ \\
Small-scale growers & 252,428 & 135,788 & 116,640 & $46 \%$ \\
\hline
\end{tabular}

Source: South African Cane Growers' Association: Statistical Data 2006/7-2015/16

Table 2: Total area under cane in hectares in Ugu District Municipality during seasons 2006/7 and 2015/16

\begin{tabular}{|lllll|}
\hline Scale of Grower & $\begin{array}{l}\text { Season } \\
\mathbf{2 0 0 6 / 2 0 0 7}\end{array}$ & $\begin{array}{l}\text { Season } \\
\mathbf{2 0 1 5 / 1 6}\end{array}$ & $\begin{array}{l}\text { Output Decline in } \\
\text { tons }\end{array}$ & Decline \\
\hline Large-scale growers & 52,288 & 48,233 & 4,055 & $8 \%$ \\
Small-scale growers & 8,840 & 4,412 & 4,428 & $50 \%$ \\
\hline
\end{tabular}

Source: South African Cane Growers' Association: Statistical Data 2006/7-2015/16

Table 3: Total area harvested in Ugu District Municipality during seasons 2006/7 and 2015/16

\begin{tabular}{|lllll|}
\hline Scale of Grower & $\begin{array}{l}\text { Season } \\
\mathbf{2 0 0 6 / 2 0 0 7}\end{array}$ & $\begin{array}{l}\text { Season } \\
\mathbf{2 0 1 5 / 1 6}\end{array}$ & $\begin{array}{c}\text { Output Decline in } \\
\text { tons }\end{array}$ & \% Decline \\
\hline Large-scale growers & 34,905 & 29,667 & 5,241 & $15 \%$ \\
Small-scale growers & 5,809 & 3,025 & 2,784 & $48 \%$ \\
\hline
\end{tabular}

Source: South African Cane Growers' Association: Statistical Data 2006/7-2015/16

The above tables provide empirical evidence of the decline in cane production within the Ugu District Municipality. Of significance is that small-scale growers appear to be most vulnerable to this, with large-scale growers appearing to be less vulnerable. For example, across all three indices of cane supply, area under cane and total areas harvested, small-scale growers faired significantly worse at 46, 50 and 48 $\%$ respectively during the comparative analyses period. By comparison, large-scale growers experienced 29,8 and $15 \%$ decline respectively during this period which, although still a major cause for concern, performed significantly better by comparison. Based on these statistics it is clear that small-scale growers, being the focus of this study, have been severely affected by the decline.

Overall, the significance of the decline lies in the fact that as a primary component of the sugarcane industry value chain, its impact is likely to extend to other value chain components such as haulage/transportation, milling, pesticides, and insurance, accounting services, fertilizer, packaging and many other components of the value chain. As such, the impact of the decline in cane production reverberates through the economy with its more likely and immediate effects being pronounced in a drastic decline in employment. In the medium to long-term, other sectors of the local economy consequently experience the shrinkage. The Sugar Industry Assessment Study Reports highlighted the following alarming statistics about Ugu (Phatisa, 2010a; Phatisa, 2010b).

- By 2009/10, sugar-cane had lost 6.5\% more hectares of land in the previous five years than other economic sectors.

- In the same period, both Umzimkhulu and Sezela Sugar Mills processed less than three million tons of cane feedstock.

- By contrast the combined capacity of both mills was 3.8 million tons of cane, indicating the dire extent of underproduction.

- The report projected that the combined tonnage would further drop to 2.6 million.

- Most alarming, the report stated that over 1000 jobs were lost during the same period.

- The same study concluded by pointing out an urgent need to plant a further 200,000 tons of sugar-cane and set out various steps and supporting interventions that are critical to achieving this as a remedial intervention if drastic, adverse changes to the socio-economic prospects of the region are to be mitigated against.

In view of the foregoing, the main aim of the research was to explore factors that account for the survival of BSSSGs in Ugu District Municipality, in the face of the severe challenges that beset the district's sugar-cane industry. The objectives of the study were to ascertain BSSSGs' perceptions of the overall sugar-cane industry, to ascertain BSSSGs' perceptions of farm-specific/micro-economic attributes that make them susceptible to failure, to ascertain whether they employ deliberate strategies to mitigate 
the causes and/or effects of the decline, and to ascertain BSSSGs' perceptions of land tenure and farm-size effects on their survivability.

\section{Literature Review}

It is widely acknowledged that the demands of globalization make it imperative for producers across the globe to stay competitive. Nowhere is this more evident than in the case of Ugu, where the overall economic performance has suffered the most adverse consequences of this phenomenon. This is most notable in the agricultural sector, which ranks among the worst casualties (UGDS, 2030 Vision, n.d.). It has been highlighted that "there is still significant development potential in the agricultural sector, even though its economic contribution to Ugu has declined over the past few years...." (COGTA, n.d., 5). Globalisation and allied pressures to stay internationally competitive are among the principle drivers behind the decline, with Ortmann (2005) confirming that both large-scale and small-scale farmers are exposed to the changes of the dynamic global trade environments caused by the liberalization of international trade markets.

Numerous other authors (Murphy, 2010; Young, Schafers \& Bruwer, 2012; Aliber \& Hart, 2009; Gerwel Proches \& Bodhanya, 2015; Gerwel Proches \& Bodhanya, 2013; Gerwel et al., 2011; SASA, n.d.; Dubb, 2013; James \& Woodhouse, 2017) provided further insights into the onerous conditions facing the sector, based on pressures from various origins. Murphy (2010) commented on the paucity of skills with reference to farmers, together with other endemic challenges that inhibit this sector from flourishing. He added that the challenges that are besetting small-scale farmers include a lack of acceptable inputs, a lack of good-quality land, insufficient smart technologies, and a lack of capital markets. All of these challenges go to the heart of the input-output/production function, ultimately affecting competiveness.

Further evidence of an absence of skills is evident in Maloa (2001), who referred to the practical steps that were undertaken to enhance the skills levels of Black growers within the South African context. In this case, the author outlined a number of steps which Black growers implemented to enhance their proficiency in productivity and therefore their growth prospects. Among such steps, the author listed "dedicated economic, resource utilization (productivity and costs minimization), database information systems, and organisational management advisory service by cane growers" (Maloa, 2001: 2). The agricultural sector is exposed to many challenges, some of which are fostered by international competition which appears to be the most severe, as well as changing weather patterns which cause a great deal of crop uncertainty, and sometimes poor yields.

Ortmann and King (2007) recommended cooperatives as a form of producer organisation for small-scale farmers within Impendle and Swayimane in KwaZulu-Natal, as an adaptive strategy for, inter alia, mitigating transaction costs, which the authors term, "horizontal coordination". Providing empirical evidence in support of horizontal coordination, Church et al. (2008) noted that small-scale farmers participating in the Dwangwa Cane Growers Limited and Kasinthula cooperatives benefited substantially from bulk-purchasing discounts arising out of horizontal coordination. This is an example of farmers pooling their purchasing power and therefore increasing their bargaining power as an adaptive strategy, wielding this to improve their position.

The prevalence of transaction costs as a prohibitive force, ostensibly necessitating individual and/or collective action by farmers, was also echoed by Ortmann and King (2010) as being among those obstacles facing small-scale growers. The authors proposed vertical integration as a mitigation measure in this case, and considered vertical integration as a strategy for enhancing access to markets.

It is clear that, under certain circumstances, economic organisation has the potential to enhance the survivability of farmers in general. However, in the case of Ugu District Municipality, two observations are relevant. Firstly, as far as sugar-cane production is concerned, Illovo Sugar is the only market, and the economies of scale required are too prohibitive to consider establishing an alternative market, which negates vertical coordination.

On the other hand, fragmented, individual cane growers, without some institutional arrangement that lobbies on their behalf, remain vulnerable as price-takers of an international commodity. For this reason, vertical and horizontal strategies are much more likely to help farmers leverage the power of 
numbers. Forming themselves into cooperatives may at least help them purchase raw materials, reduce transportation costs, and access accounting services so that they may obtain bulk-buying discounts.

While there is overwhelming support for an inverse relationship between farm size and productivity, based on empirical research findings (Assunção \& Ghatak, 2003; Heltberg, 1998; Barrett, 1996), consensus remains elusive on its fundamental causes. Authors such as Barrett (1996) contend that it is not the farm size that is behind the inverse relationship, but rather market failure or miscalculation of some other yet-to-be-known underlying variable. Making a crucial observation in this regard, he noted that, if the inverse relationship were to be explained purely on farm size alone, it would provide a strong argument for the subdivision of farms handed over to land-redistribution recipients, owing to "inherently greater efficiencies" associated with smaller farms. For South Africa, this phenomenon would hold significant relevance, given the fact that the country is grappling with the problem of land redistribution amid discouraging results on productivity and other fronts.

It is clear that there is a plethora of challenges faced by contemporary farming. While some challenges arise from economic globalisation via the Structural Adjustment Program (Eakin, Tucker \& Castellanos, 2006; Leichenko \& O'Brien, 2002; Bryceson, 1999), others stem from a lack of access to capital and markets, extreme weather patterns with attendant effects on infrastructure, or severe droughts. Further challenges, particularly in the case of South Africa, include imports of capital goods and inputs which make the domestic farming sector susceptible to currency fluctuations. Over and above these adverse factors, the literature has exposed the paucity of technical and business acumen, especially among the emerging farming community, which is characterised by an across-the-board high rate of business failure, all of which points to endemic weakness in the farming sector.

\section{Methodology}

The qualitative research approach was employed. Data were collected using convenience and snowball sampling. Fifteen respondents from two areas in which sugar-cane is grown within the district, namely Qhubekani Farmers Association, and Minini-Mfume Farmers Association, were interviewed.

Data were collected using semi-structured interviews. Each respondent received an Informed Consent Form detailing the purpose of the study. Ethical clearance approval was obtained. Interviews were conducted in the vernacular of the respondents, lasting from 45 minutes to an hour, depending on the level of depth that flowed from the discussions. The interview protocol, which comprised 15 openended questions, was designed to elicit the challenges, views, mindsets and perceptions of the participants, in respect of the research topic and study objectives.

Thematic analysis was used to analyse the data from the interviews by identifying themes and patterns. Given that this was a qualitative study, careful attention was paid to ensure that the process of transcribing and analysing data was credible, trustworthy and dependable. Guiding principles outlined by Corley (2012) were followed. 


\section{Results}

Table 4: Details of respondents

\begin{tabular}{|c|c|c|c|c|c|c|c|c|c|c|}
\hline 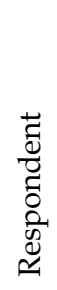 & $\stackrel{80}{4}$ & 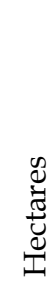 & $\begin{array}{l}\frac{0}{0} \\
\text { 量 } \\
0 \\
0 \\
0\end{array}$ & $\begin{array}{l}\dot{0} \\
\frac{0}{0} \\
0 \\
0\end{array}$ & 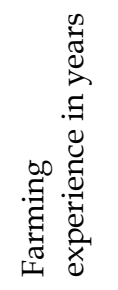 & 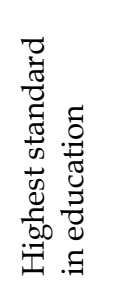 & 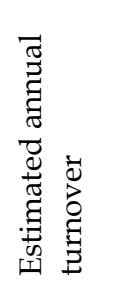 & 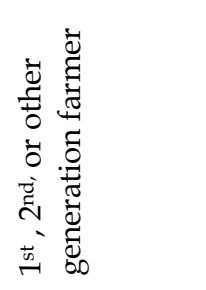 & 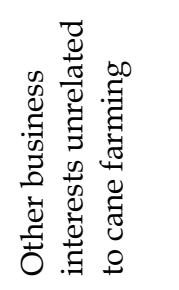 & 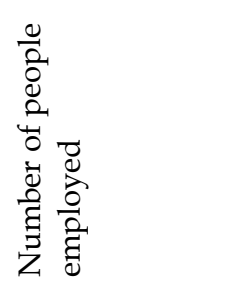 \\
\hline 1 & 55 & $\begin{array}{l}15 \\
\text { ha }\end{array}$ & No & Male & 2 years & Std 10 & R350,000 & $2^{\text {nd }}$ Generation & Yes & $\begin{array}{l}300 \text { in the season } \\
\text { Aug-Oct }\end{array}$ \\
\hline 2 & 45 & $\begin{array}{l}5 \\
\text { ha }\end{array}$ & Yes & Female & 4 years & Std 9 & $\mathrm{R} 600,000$ & $1^{\text {st }}$ Generation & Yes & $\begin{array}{l}\text { Farming } \\
\text { conducted through } \\
\text { contractor scheme }\end{array}$ \\
\hline 3 & 64 & $\begin{array}{l}2 \\
\text { ha }\end{array}$ & Yes & Male & 8 years & Std 2 & $\mathrm{R} 672,000$ & $2^{\text {nd }}$ Generation & No & $\begin{array}{l}\text { Farming } \\
\text { conducted through } \\
\text { contractor scheme }\end{array}$ \\
\hline 4 & 80 & $\begin{array}{l}4 \\
\text { ha }\end{array}$ & Yes & Male & 22 years & Std 10+ & $\mathrm{R} 26,000$ & $1^{\text {st }}$ Generation & No & $\begin{array}{l}\text { Farming } \\
\text { conducted through } \\
\text { contractor scheme }\end{array}$ \\
\hline 5 & 60 & $\begin{array}{l}20 \\
\text { ha }\end{array}$ & Yes & Male & 32 years & Std 8 & $\mathrm{R} 50,000$ & $2^{\text {nd }}$ Generation & No & $\begin{array}{l}\text { Farming } \\
\text { conducted through } \\
\text { contractor scheme }\end{array}$ \\
\hline 6 & 62 & $\begin{array}{l}3 \\
\text { ha }\end{array}$ & Yes & Male & 1 year & Std 10 & $\begin{array}{l}\text { Not } \\
\text { available }\end{array}$ & $1^{\text {st }}$ Generation & $\begin{array}{l}\text { Employed } \\
\text { full-time } \\
\text { elsewhere }\end{array}$ & $\begin{array}{l}\text { Farming } \\
\text { conducted through } \\
\text { contractor scheme }\end{array}$ \\
\hline 7 & 57 & $\begin{array}{l}25 \\
\text { ha }\end{array}$ & Yes & Male & 10 years & Std 10+ & $\mathrm{R} 40,000$ & $2^{\text {nd }}$ Generation & $\begin{array}{l}\text { Taxi and } \\
\text { full-time } \\
\text { employment } \\
\text { elsewhere }\end{array}$ & $\begin{array}{l}\text { Farming } \\
\text { conducted through } \\
\text { contractor scheme }\end{array}$ \\
\hline 8 & 64 & $\begin{array}{l}4 \\
\text { ha }\end{array}$ & Yes & Male & 1 year & Std 2 & $\begin{array}{l}\text { Not } \\
\text { available }\end{array}$ & $1^{\text {st }}$ Generation & Taxi & As above \\
\hline 9 & 53 & $\begin{array}{l}35 \\
\text { ha }\end{array}$ & Yes & Male & 31 years & Std 8 & R300,000 & $1^{\text {st }}$ Generation & Taxi & 13 employees \\
\hline 10 & 64 & $\begin{array}{l}4 \\
\text { ha }\end{array}$ & Yes & Male & 24 years & $\begin{array}{l}\text { Never } \\
\text { attended } \\
\text { School }\end{array}$ & $\mathrm{R} 100,000$ & $1^{\text {st }}$ Generation & $\begin{array}{l}\text { Spaza shop } \\
\text { and shebeen }\end{array}$ & $\begin{array}{l}\text { None (because of } \\
\text { season) }\end{array}$ \\
\hline 11 & 71 & $\begin{array}{l}12 \\
\text { ha }\end{array}$ & No & Male & 20 years & Std 6 & $\begin{array}{l}\text { Don't } \\
\text { know }\end{array}$ & $1^{\text {st }}$ Generation & None & $\begin{array}{l}\text { Farming } \\
\text { conducted through } \\
\text { contractor scheme }\end{array}$ \\
\hline 12 & 44 & $\begin{array}{l}5 \\
\text { ha }\end{array}$ & Yes & Male & 12 years & Std 10 & $\begin{array}{l}\text { Don't } \\
\text { know }\end{array}$ & $2^{\text {nd }}$ Generation & $\begin{array}{l}\text { Full-time } \\
\text { employee } \\
\text { elsewhere }\end{array}$ & As above \\
\hline 13 & 71 & $\begin{array}{l}3 \\
\text { ha }\end{array}$ & Yes & Male & 11 years & Std 6 & $\mathrm{R} 8,000$ & $1^{\text {st }}$ Generation & None & $\begin{array}{l}\text { None at present, } \\
\text { owing to season }\end{array}$ \\
\hline 14 & 54 & $\begin{array}{l}3 \\
\text { ha }\end{array}$ & Yes & Male & 17 years & Std 8 & $\mathrm{R} 18,300$ & $1^{\text {st }}$ Generation & $\begin{array}{l}\text { Gum-tree } \\
\text { felling, Pig } \\
\text { farming }\end{array}$ & $\begin{array}{l}\text { None at present, } \\
\text { owing to season }\end{array}$ \\
\hline 15 & 66 & $\begin{array}{l}5 \\
\text { ha }\end{array}$ & Yes & Male & 17 years & Std 10 & $\mathrm{R} 36,000$ & $2^{\text {nd }}$ Generation & $\begin{array}{l}\text { Vegetable } \\
\text { farming }\end{array}$ & $\begin{array}{l}4 \text { for vegetables; ( } 7 \\
\text { to } 8 \text { for cane) }\end{array}$ \\
\hline
\end{tabular}

Table 4 shows that BSSSGs in this sample were predominantly male. This could be as a result of the patriarchal nature of the research setting. The average age of the respondents was 60 . This raises questions regarding the present- and medium-term future of farming. In addition, one farmer indicated during the interviews that physical exertion required by farming was very taxing on his body. Against this backdrop, in which comparatively low levels of mechanization were noted, this observation apropos of age becomes pertinent. On the other hand, age may have its own positives in the sense that these farmers are highly experienced in their work. 
Over half of the respondents fell within the category of Standards 6-10. Other respondents had achieved an educational level above Standard 10, whereas some had only attended school to Standard 5. One respondent had never attended school. The comparatively low levels of education raise questions about the adaptability of respondents, especially regarding the sophisticated decision tools and agronomic practices that seem to be demanded in contemporary farming.

Just under half of the respondents were second-generation farmers. This is positive in the sense that, should this trend persist, it may mean that there is a likelihood of a family member taking over the family farm from current BSSSGs in the event of retirement or death. This may also mean that the sector is able to attract new farmers into its fold.

Table 4 shows the extent of employment created per respondent at one particular time. The first observation to make about employment trends are that they are seasonal, lasting only during the farming and harvesting season. The second, and most intriguing aspect, is that in just over half of the cases, no employment was recorded. The reason for this is that the farming is conducted through a third party contracting under the government-sponsored scheme. This has given rise to the phenomenon of "passive farming".

A further observation is that if one excludes income of the four top earners from the calculations, the average income per respondent falls drastically to R4,166 per month, with the majority of these respondents earning R50,000 or less per annum. A further aspect of concern revealed by these figures is the number of cases in which non-availability of data was recorded, calling into question the farmers' ability to manage the microeconomic aspects of their businesses. Overall, the figure depicts an income distribution that indicates that BSSSGs could, in the main, be struggling financially.

Perception of the overall state of Ugu sugar-cane industry

A total of six respondents ( $40 \%$ of the sample) assessed the industry as being on the decline, as opposed to five ( $33 \%$ of the sample) who felt that the industry was stabilising. This difference in the given assessments of the industry is cause for great concern. It may also mean that there are no measures to deal with the stagnation/decline at farm level, for the farmers concerned. What was also interesting to note is that, apart from the remaining two respondents who assessed the industry as being "stable", two did not know, or were undecided. Overall, there is an urgent need for the BSSSGs to appreciate and become more aware of the gravity of the industry's predicament.

\section{Intention to expand or decrease sugar-cane planting in the near future}

An overwhelming number of BSSSGs $(80 \%)$ indicated their plans to increase sugar-cane planting. Within the context of an overall industry that is ailing, this observation is encouraging, and at face value indicates a guaranteed participation of BSSSGs in the foreseeable future.

\section{Factors that exacerbate the decline, leading to farms going bankrupt}

An analysis of the responses revealed that there is a strong apportionment of blame among BSSSGs for the manner in which the government and the mill handled the Recapitalisation Programme. These respondents were the current recipients of the Recapitalisation Programme, where farming is done on their behalf by a third party who is paid by the government via the miller under the programme. Participants are only required to provide land and the rest is done under the contractor farming programme. This study showed that this might have attracted people who were not of the right calibre for farming, who possibly for all intents and purpose were neither farmers nor entrepreneurs. Further criticism was levelled at the government by respondents through its implementation of other programmes such as the Reconstruction and Development Programme (RDP) and the Land Restitution Programme. For example, $27 \%$ of the sample blamed the government and the mill for the Recapitalisation Plan and the Contract Farming Programme, with all of the BSSSGs alleging misappropriation of funds intended for this programme.

Similarly, $27 \%$ of the respondents blamed land restitution and competition from other farming sectors, which, according to the respondents, were responsible for the declining share of sugar-cane in land allocation. Surprisingly, these respondents limited this competition to the forestry sector and the government's RDP Programme, or simply cane land which they observed being turned into residential 
use, either through formal proclamation, or informally. Respondents excluded commodities such as macadamia nuts and tea-tree plantations.

The next group of responses to this question referred to cost competitiveness, import effects, and the fact that the industry structure favours everyone from the contractor to the cane hauler, transporter, and the mill, with genuine instances in which the farmer gains nothing from the harvest. This group of respondents accounted for $20 \%$ of the interviewees. Other notable responses to this question were a failure by BSSSGs to reinvest in their businesses, government dependency by BSSSGs (characterised by unfulfilled expectations in this regard), a lack of farming skills amongst BSSSGs, and high transport costs.

Implementation of microeconomic measures that mitigate the decline

An analysis of the responses to the above question revealed that two respondents claimed that they were not aware of the industry's deterioration. Upon further probing, this became a cause for concern when it appeared that one of the respondents was actively involved in and sits on various committees that deal with matters pertaining to the sugar-cane industry in the district. He argued that the discourse that he was exposed to in these committees indicated that the industry was on an upward trend.

The responses indicated a significant adoption of improved agronomic practices. It is also interesting to note that the mill was mentioned by at least one respondent as playing a pivotal role in the propagation of new seedlings, and as being responsible for research into improved cane cultivars with direct benefits to BSSSGs.

One respondent claimed that he did not implement any agronomic practices because there was nothing wrong with the industry, but that the problem lay with the mill and the government around the Recapitalisation Programme, which it claimed would take care of all problems. Yet, this respondent was responsible for the most employment created in one season, and his turnover figures placed him in the top-earning income bracket. This respondent may have perhaps implemented improved agronomic practices, and his responses could have merely been a reflection of his feelings towards the Recapitalisation Programme.

It may be argued that the farmers still retain the ultimate responsibility for any improvement in agronomic practices as business owners, irrespective of outside interventions, such as the Recapitalisation Programme. A significant number of respondents claimed to be implementing agronomic practices; their answers in this regard were backed with a certain degree of conviction. Some respondents displayed positive turnover figures and a propensity for income diversification, with three of the farmers having gone out and forged relationships with established commercial farmers, whom they credited with the improvements they subsequently achieved.

The last notable group of responses elicited under this question revealed a "passive" farming phenomenon. These respondents were recipients of the Recapitalisation Programme, in which farming is conducted on their behalf, under the programme, by a third party paid by the government, via the mill. This group constituted $40 \%$ of the sample and were a source of great concern given that, in the main, they are hardly distinguishable from landlords who offer land for commercial activity and in return take rent, without being hands-on in the actual business. One encouraging aspect of this is that one respondent appeared to be very knowledgeable on the agronomics of farming. She was actively attending training to improve her technical farming skills. It was also interesting that the mill, despite receiving much criticism, also received praise concerning the propagation of a new variety of seedlings, which were not only easier to plant, thereby cutting production costs substantially, but also had a shorter harvest cycle. Furthermore, respondents claimed that these varieties were resistant to numerous cane diseases.

\section{Effects of Farm Size on Survivability}

An analysis of the responses in this regard showed that $40 \%$ of respondents were neutral with respect to farm size as a factor in survivability. A further $47 \%$ of respondents felt advantaged by their small-size farm in one way or another. The remaining $13 \%$ of respondents felt disadvantaged by their small farm size. The latter group of respondents generally associated small farm size with lower profitability, while others in the same group indicated that it posed constraints in terms of expanding, which there was a definite appetite for among BSSSGs, evident in the question that dealt with industry outlook. 


\section{Discussion}

The study aimed to explore factors that account for the survival of BSSSGs within the Ugu District Municipality in KwaZulu-Natal, South Africa. The research highlighted the significance of passive farming, the lack of technological uptake, and income diversification strategies.

The study revealed a significant amount of passive farming among BSSSGs at $40 \%$ prevalence, which, upon further investigation, was found to have been perhaps linked to the manner in which the Recapitalisation Programme had been implemented. These findings regarding passive farming simultaneously confirmed the scarcity of technical farming proficiency and business acumen, as asserted by Maloa (2001) and Murphy (2010). Furthermore, based on the fact that these farmers played no part in their farming operations, these BSSSGs were presumed to be lacking in key attributes that are deemed by several researchers to be drivers of success in business (Rauch \& Frese, 2000; Shane, Locke \& Collins, 2003; Baum \& Locke, 2004; Sumner, 2011; Young et al., 2012).

The study also found that, among the BSSSGs, a small percentage were highly motivated, directly involved in their farming businesses, and, to some degree, displayed the traits needed for success in business as alluded to above, including a perception of themselves as entrepreneurs upon whose efforts and decisions the success of their operations depended. The attributes displayed by these respondents are consistent with the motivational and individual psychological traits put forward by Shane et al. (2003), and Baum and Locke (2004), amongst others. These respondents distinguished themselves with a comparatively high level of technical acumen in farming practices, had forged relationships with their commercial farmer counterparts, and were responsible for significant employment creation and high turnover. This level of proficiency was more in line with the prediction of Maloa (2001) and Ortmann (2005); however, all the respondents lacked the degree of technological integration in their businesses that was envisaged by Van den Berg and Smith (2005).

Another finding was that the respondents fell short of the expectations implied by the assertions of authors such as Sumner (2011), Beckford et al. (2007), and Genis (2012), when it comes to the degree of integration of measures that these authors prescribed as critical for success. In addition, these BSSSGs had comparatively low capitalisation levels, which is an indication of farm operations that are relatively small and largely constrained in their level of absorption of technology and other contemporary facets of farming, as envisaged by Ortmann (2005) and Van den Berg and Smith (2005). Conversely, passive farming is consistent with the predictions of Olawale and Garwe (2010), and Urban and Naidoo (2012), who spoke about the general lack of skills in the SMME sector, which in turn causes a high rate of failure.

The findings on the low levels of turnover and profitability experienced by the BSSSGs appear to contradict the assertions of several authors such as Ortmann (2005), Van den Berg and Smith (2005), and Sumner (2011), which in turn raises serious doubts as to the BSSSGs' competitiveness. However, at an average of R49 992 per respondent per annum, the income that accrues to BSSSGs is substantially higher than the R5, 000 projected annual start-up incomes for the Recapitalisation Programme (Kaye, 2013). The picture changes slightly, and income drops, when calculations are based on the lower-income bracket of respondents, whose income fell between R0-150,000 at an average of R21 429 per respondent per annum.

The majority of BSSSGs appeared to be operating largely at a survivalist level, in which the scale of farming operations is negligible. Even those belonging to a high-income bracket had a lower level of mechanization than those envisaged for commercial farmers in terms of degree of mechanisation, labour force, transport facilities, and access to credit (Kaye, 2013). It is not surprising that the majority of respondents stated a lack of transport, or high transport costs, and the general problems of logistics for sugar-cane hauling and transporting to the mill, as among their major problems.

Passive farmers are often detached from their farms, which perhaps means that they cannot be regarded as farmers, in the strictest sense of the word. Viewed in light of existing literature, this situation poses serious challenges for the state of BSSSGs' survivability, and raises general concerns for the industry as a whole. Regarding these farmers, practices of critical importance to them and the industry, as espoused by authors such as Beckford et al. (2007) and Ortmann (2005), with regard to the embracing of relevant technology, were absent. The study further found that this group of farmers was particularly lacking an appreciation of the agronomic practices that drive success in the industry, which was termed the bedrock of a competitive industry, by Ortmann (2005). These findings are at odds with the farmer 
envisaged by Maloa (2001), who is not only adept at leveraging information systems as a business operation managerial tool, but is also highly proficient in both technical farming skills and business acumen. These findings are furthermore at odds with an entrepreneur, as envisaged by various authors such as Young et al. (2012) and Van den Berg and Smith (2005).

The findings regarding agronomic practices indicated that an overwhelming majority of respondents appeared to be following basic agronomic practices. As such, there appeared to be no concerns regarding fertilisation, application of pesticides, improved variety of seedlings, and many basic agronomic practices. However, one area that stood out as lacking was in terms of the farmers' uptake of decision-support tools. Evidence of this is that not a single respondent indicated that he/she was using a computer as a decision-support tool. In this context, it should be noted that Van den Berg and Smith's (2005) crop-modelling support-decision system requires some degree of computer literacy. This further contradicts Maloa (2001), who envisaged a farmer leveraging information systems as a tool to enhance business decision-making and overall farming proficiency. This represents a serious limitation in the BSSSGs' capacity to move a notch higher in, for example, employing the crop-growth modelling as envisaged by Van den Berg and Smith (2005). Another observation was that, although farming practices have evolved to such an extent that there is a certain degree of automation, practices remained at a marginal level amongst the BSSSGs. This is another area of possible improvement, the degree of mechanisation likely to be a factor in international competitiveness.

At $67 \%$ overall diversification propensity, the BSSSGs seemed to fare reasonably well in terms of diversification strategies. This supports the patterns observed by authors such as Reardon and Taylor (1996), Bryceson (1999), Barrett and Reardon (2000), Barrett et al. (2005), Eakin et al. (2006), Beckford et al. (2007), Wouterse and Taylor (2008), and Aliber and Hart (2009). Whilst the sugar-cane industry appears to provide substantial opportunities for diversification, a sizeable number of BSSSGs have diversified outside of the industry. Three respondents indicated that they had business interests in the taxi industry; one had a successful construction business; one was retailing in liquor and groceries; one was involved in other crops such as vegetables; and another was involved in tree-felling and piggeries. In total, this diversification accounted for 47 percent. The majority of these respondents also extended their diversification activities to contract farming. A further three were employed elsewhere to make up $67 \%$ income diversification. This income-diversification pattern occurred from the mid-income category to the top-earning bracket.

As such, while these findings support the prediction of most authors regarding diversification behaviour by small-scale farmers, they also differ from the variant of Beckford et al. (2007), which predicts farm fragmentation as an integral part of their diversification strategy to take advantage of spatial variations and environmental conditions. Also, noteworthy in the study, the majority of diversification happens outside of the farming enterprise, thus confirming the predictions of Reardon and Taylor (1996), Eakin et al. (2006), and Wouterse and Taylor (2008). Furthermore, this confirms Barrett and Reardon's (2000) previous findings, which noted that non-farm income sources constituted $45 \%$ of total income. Likewise, this somewhat supports Barrett et al. (2005), who noted that in North Central Kenya, the highlands of Rwanda, and Cote d'Ivore, livelihood strategies associated with non-farming activities offer the most income.

Three of the respondents were employed full-time elsewhere; this kind of income diversification is not the most ideal. This statement is based on the reasoning that full-time employment places its own onerous demands on individuals that ordinarily would cause grave conflicts of interest, ultimately leading to one of the jobs being seriously compromised. However, in this particular instance, passive farming through third-party contract farming under the Recapitalisation Programme, makes this ordinarily untenable situation possible. As such, a high percentage of BSSSGs seemed reasonably diversified; diversity was spread across income opportunities to avoid being exclusively dependent on sugar-cane farming income. This is evidence that BSSSGs in the sample were able to hedge income variations from sugar-cane farming by relying on other sources. At the same time, this may raise other questions about those BSSSGs who hold a permanent job while participating in the industry. 


\section{Conclusion}

The research indicated that successful BSSSGs have been creative in dealing with their problems, including forging strategic partnerships with commercial farmers. They stated that these linkages had greatly enhanced their farming operations. This group had also shown themselves to be generally aware of the decline of the industry, attributing it to globalisation and imports. The group was largely unhappy with the role of the government and the mill regarding the implementation of the Recapitalisation Programme, notwithstanding this, these respondents have confronted their challenges head on.

At the other extreme, there is a group of passive farmers, an unintended consequence of the Recapitalisation Programme, whereby participants are only required to provide land. The rest is conducted on their behalf under the contractor-farming programme. Entrepreneurship, and the key role it plays in business survival, was reiterated. There may be "spoon-feeding" and a climate in which it is possible for the misallocation of harvests, given that there is a group of farmers who are not sufficiently knowledgeable about, even detached from, their farming operations. Some farmers may not take full responsibility for any of the problems afflicting the industry, deflecting the blame on the government and the mill. It is important to note, however, that even the progressive farmers blame the government and the mill for their problems, particularly accusing the government of inculcating a culture of dependency, among other things.

Another highlight of the study was the high optimism levels regarding the industry, which was gleaned from the respondents' intentions to expand sugar-cane farming. Even more interesting in this regard is the fact that they cited a profit motive as their rationale.

Throughout the study, a deep sense of mistrust was directed at the government, the mill, and the contractors. It is thus recommended that future phases of the Recapitalisation Programme be implemented alongside genuine partnerships between the mill, the provincial government, and farmers, through the farmers' associations. Under the revised implementation model, these three organisations could establish a representation model which would formulate, plan, and agree upfront on specific targets and outcomes, together with the modus operandi, including a monitoring and evaluation framework. While the project is being implemented, these parties should meet regularly and share information and concerns, as guided by the predetermined and agreed targets. Issues such as the selection and role of contractors, their performance, and the overall financial information of the project, should be shared in this forum to prevent accusations of impropriety by any party, and to engender co-ownership of the project.

A structured programme which would enhance technical proficiency and business acumen should thus be integrated into future phases of the Recapitalisation Programme. To this end, participants should be placed within business-incubator models for intensive training in sugar-cane farming, and thereafter be sent back to their farms to apply the knowledge that they gained. Respondents should be assigned mentors who could ensure follow-up training, assess how these emerging farmers are coping with practical challenges, and evaluate the way in which the theoretical training assists these farmers to adapt to the practical demands. Information obtained through mentorship follow-up should then be fed back into the system to enhance areas of strength, whilst improving on weaknesses. To this end, the role of the contractor system must be transitional, and should not be used as a substitute for the farmers.

This study falls within a qualitative and non-positivist paradigm which is geared towards understanding a phenomenon in greater depth, with a view to eliciting context-specific knowledge and insights. Therefore, unlike a quantitative design, it did not aim to test hypotheses, nor to generalise results from the study. The study did not intend to test relationships between any variables. The study limitations therefore include a limited sample size, with only a very limited number of individuals in one stakeholder group. The study should therefore be interpreted with these limitations in mind.

Future research could target a larger sample to include key diverse stakeholder groups. Such a study could be of a mixed-methods nature. Another area of possible future research is a comparative study of the degree of institutionalisation of automation/mechanization, and the extent to which this correlates with industry success between local small-scale sugar-cane growers and their international counterparts. A related study could determine the differences in size of capitalisation of local farmers and their international counterparts. 


\section{References}

Aliber, M. \& Hart, T.G.B. (2009), 'Should Subsistence Agriculture be Supported as a Strategy to Support Rural Food Security?', Agrekon, Vol. 48, No. 4, pp. 434-458.

Assunção, J.J. \& Ghatak, M. (2003), 'Can observed heterogeneity in Farmer Ability Explain the Inverse Relationship between Farm Size and Productivity', Economics Letters, Vol. 80, No. 2, pp. 189-194.

Barrett, C.B. (1996). 'On Price Risk and the Inverse Farm Size-Productivity Relationship', Journal of Development Economics, Vol. 51, No. 2, pp. 193-215.

Barrett, C.B. \& Reardon, T. (2000), 'Asset, Activity and Income Diversification among African Agriculturalists: Some Practical Issues', Working Paper 2000-19, Cornell University, Ithaca, New York, USA.

Barrett, C.B., Bezuneh, M., Clay, D.C. \& Reardon, T. (2005), 'Heterogeneous Constraints, Incentives and Income Diversification Strategies in Rural Africa', Quarterly Journal of International Agriculture, Vol. 44, No. 1, pp. 37-60.

Baum, J.R. \& Locke, E.A. (2004), 'The Relationship of Entrepreneurial Traits, Skill and Motivation to Subsequent Venture Growth', Journal of Applied Psychology, Vol. 89, No. 4, pp. 587.

Beckford, C., Barker, D. \& Bailey, S. (2007), 'Adaptation, Innovation and Domestic Food Production in Jamaica: Some Examples of Survival Strategies of Small-Scale Farmers', Singapore Journal of Tropical Geography, Vol. 28, No. 3, pp. 273-286.

Bryceson, D.F. (1999), 'African Rural Labour, Income Diversification and Livelihood Approaches: A Longterm Development Perspectives', Review of African Political Economy, Vol. 26, No. 80, pp. 171-189.

Church, A.D, Groom, G.M, Thomson, D.N. \& Dlamini, V.R. (2008), 'Small-Scale Cane Grower Development Models: Some Lessons from Sub-Saharan Africa', Proceedings of the South African Sugar Technology Association, Vol. 81, pp. 116-127.

COGTA, n.d. Ugu District Municipality Profile. Available at www.nda.agric.za/doaDev/22SMS/docs/PROFILES\%202011\%20UGU\%20AUG.docx

Corley, K. (2012), 'Publishing in AMJ-Part 7: What's Different about Qualitative Research?', Academy of Management Journal, Vol. 55, No. 3, pp. 509-513.

Davis, R., Zunckel, K. \& Kruger, T. (2012), ‘KZN Department of Economic Development \& Tourism Profiling District Economic Drivers. Phase 5 - Spatial Economic Overview Ugu District Municipality. Available at http://www.tikzn.co.za/resources/docs/general/District_ProfileuGu.pdf

Dubb, A. (2013), 'The rise and decline of small-scale sugarcane production in South Africa: A historical perspective', Journal of Agrarian Change, Vol. 16, No. 4, pp. 518-542.

Eakin, H., Tucker, C. \& Castellanos, E. (2006), 'Responding to the Coffee Crisis: A Pilot Study of farmers' Adaptation in Mexico, Guatemala and Honduras', The Geographical Journal, Vol. 172, No. 2, pp. 156171.

Genis, A. (2012), The Changing Nature of Large-Scale Commercial Farming and Implications for Agrarian Reform: Evidence from Limpopo, Western Cape and Northern Cape, Working Paper 24, PLAAS, UWC, Bellville.

Gerwel, C., Hildbrand, S., Bodhanya, S. \& Bezuidenhout, C. (2011), Systemic approaches to understand the complexities at the Umfolozi and Felixton mill areas. Proceedings of the 84th Annual Congress of the South African Sugar Technologists' Association (SASTA), pp. 177-181, Durban, South Africa, 17-19 August 2011.

Gerwel Proches, C.N. \& Bodhanya, S. (2015), 'Exploring stakeholder interactions through the lens of complexity theory: lessons from the sugar industry', Quality and Quantity: International Journal of Methodology, Vol. 49, No. 6, pp. 2507-2525.

Gerwel Proches, C.N. \& Bodhanya, S. (2013), 'An analysis of multi-stakeholder interactions in the sugar industry using a social complexity framework', Problems and Perspectives in Management, Vol. 11, No. 4, pp. 77-85.

Heltberg, R. (1998), 'Rural Market Imperfections and the Farm Size-Productivity Relationship: Evidence from Pakistan', World Development, Vol. 26, No. 10, pp. 1807-1826.

James, P. \& Woodhouse, P. (2017), 'Crisis and Differentiation among Small-Scale Sugar Cane Growers in Nkomazi, South Africa', Journal of Southern African Studies, Vol. 43, No. 3, pp.535-549. 
Kaye, S. (2013), 'Case Study: Local Economic Development (LED) in the Agricultural Sector: Illovo and the Sezela Mill Cane Small Growers' Renaissance', Skills at Work: Theory E Practice, Vol. 6, No. 1, pp. 4961.

Leichenko, R.M. \& O’Brien, K.L. (2002), 'The Dynamics of Rural Vulnerability to Global Change: The Case of Southern Africa', Mitigation and Adaptation Strategies for Global Change, Vol. 7, No. 1, pp. 1-18.

Maloa, M.B. (2001), Sugar Cane: A Case as Development Crop in South Africa, Conference on Land Reform and Poverty Alleviation in Southern Africa, Pretoria, 4-5 June, pp. 1-11.

Murphy, S. (2010), Changing Perspectives: Small Scale Farmers, Markets and Globalisation (Revised Edition), IIED/Hivos, London/The Hague.

Olawale, F. \& Garwe, D. (2010), 'Obstacles to the Growth of New SMEs in South Africa: A Principal Component Analysis Approach', African Journal of Business Management, Vol. 4, No. 5, pp. 729-738.

Ortmann, G.F. (2005), 'Promoting the Competitiveness of South African Agriculture in a Dynamic Economic and Political Environment', Agrekon, Vol. 44, No. 3, pp. 286-320.

Ortmann, G.F. \& King, R.P. (2007), 'Agricultural Cooperatives II: Can they Facilitate Access to Small-Scale Farmers in South Africa to Input and Product Markets', Agrekon, Vol. 46, No. 2, pp. 219-244.

Ortmann, G.F. \& King, R.P. (2010), 'Research on Agri-Food Supply Chains in Southern Africa involving Small-Scale Farmers: Current Status and Future Possibilities', Agrekon, Vol. 49, No. 4, pp. 397-417.

Phatisa, 2010a. 'Ugu Sugar Industry Report', Volume 2, Complication Report. Unpublished.

Phatisa, 2010b. 'Ugu Sugar Industry Report', Volume 3, Resolution Report. Unpublished.

Rauch, A. \& Frese, M. (2000), 'Psychological approaches to entrepreneurial success. A general model and an overview of findings', International Review of Industrial \& Organizational Psychology, Vol. 15, pp. 101-142.

Reardon, T. \& Taylor, J.E. (1996), 'Agro-climatic Shock, Income Inequality and Poverty: Evidence from Burkina Faso', World Development, Vol. 24, No. 5, pp. 901-914.

SASA, n.d. South African Sugar Industry Directory 2016/2017. Available at

http://www.sasa.org.za/Files/Sugar\%20Industry\%20Directory\%202016.pdf

Shane, S., Locke, E.A. \& Collins, C.J. (2003), 'Entrepreneurial Motivation', Human Resource Management Review, Vol. 13, No. 2, pp. 257-279.

South African Cane Growers' Association 2017, Statistical Data: 2006/7-2015/16. Mount Edgecombe, Cane growers.

Sumner, M.E. (2011), 'Out of sight out of mind: Subsurface Factors in Sugarcane Yield Decline', Proceedings of the South African Sugar Technology Association, Vol. 84, pp. 1-27.

Ugu District Municipality (2012), 'Ugu District Growth and Development Strategy (2012)', Available on http:/ / www.kznppc.gov.za/images/downloads/DGDP/Galebe/DC $\% 2021 \% 20 \mathrm{Ugu} \% 20 \mathrm{Final} \% 20$ DGDS\%20Report.pdf

Ugu District Municipality (n.d.), ‘Ugu District Municipality Integrated Development Plan (IDP)2016/2017', Available at

http://ugu.gov.za/Documents/IDP/2016-17\%20\%20IDP\%20Review\%20_Part1.pdf

Urban, B. \& Naidoo. R. (2012), ‘Business Sustainability: Empirical Evidence on Operational Skills in SMEs in South Africa', Journal of Small Business and Enterprise Development, Vol. 19, No. 1, pp. 146-153.

Van den Berg M. \& Smith, M.T. (2005), 'Crop Growth Models for Decision Support in the South African Sugar Industry', Proceedings of the South African Sugar Technology Association, Vol. 79, pp. 495-509.

Wouterse, F. \& Taylor, J.E. (2008), 'Migration and Income Diversification: Evidence from Burkina Faso', World Development, Vol. 36, No. 4, pp. 625-640.

Young, L., Schaffers, L. \& Bruwer, J. (2012), 'South African Informal Businesses Sustainability in the Cape Town Central Business District: The Power of Internal Financial Controls', African Journal of Business Management, Vol. 6, No. 45, pp. 11321-11326. 